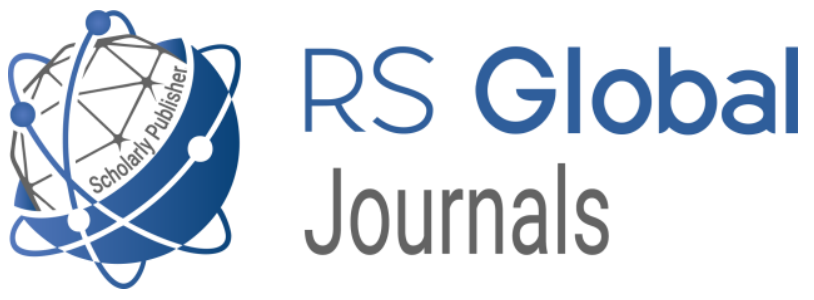

Scholarly Publisher

RS Global Sp. z O.O.

ISNI: 0000000484952390

Dolna 17, Warsaw, Poland 00-773

Tel: +48226022703

Email: editorial_office@rsglobal.pl

JOURNAL International Journal of Innovative Technologies in Social Science

p-ISSN

$2544-9338$

e-ISSN

2544-9435

PUBLISHER

RS Global Sp. z O.O., Poland

ARTICLE TITLE

URBAN MUSIC OF ALEXANDRAPOLE AND KOMITAS

AUTHOR(S)

ARTICLE INFO

Harutyunyan H. H. (2021) Urban Music of Alexandrapole and Komitas. International Journal of Innovative Technologies in Social Science. 3(31). doi: 10.31435/rsglobal_ijitss/30092021/7687

DOI https://doi.org/10.31435/rsglobal_ijitss/30092021/7687

RECEIVED 10 August 2021

ACCEPTED

18 September 2021

PUBLISHED

23 September 2021

LICENSE

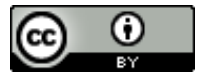

This work is licensed under a Creative Commons Attribution 4.0 International License.

(C) The author(s) 2021. This publication is an open access article. 


\title{
URBAN MUSIC OF ALEXANDRAPOLE AND KOMITAS
}

\author{
Harutyunyan H. H., PhD in Art, Shirak Centre for Armenian Studies of NAS RA, Gyumri, \\ Republic of Armenia
}

DOI: https://doi.org/10.31435/rsglobal_ijitss/30092021/7687

\section{ARTICLE INFO}

Received 10 August 2021

Accepted 18 September 2021

Published 23 September 2021

\section{KEYWORDS}

Komitas, Alexandrapol, Ašugh, Society, Song, Tradition.

\begin{abstract}
The ašugh society in Alexandrapol (now Gyumri) emerged and developed under the immediate effect of historical-cultural processes. This society carried out an important mission with the public acknowledgement it possessed. It was an embodiment of the new qualities in the Armenian national thought in all the spheres of the ašugh school: ideological, propagandistic, music-poetic, etc. Among the songs leaning towards the Near East ašugh traditions that constituted the huge heritage of about forty ašułs, the songs based on Armenian verses display the modal, prosodic and stylistic features of Armenian monodic music. My paper presents the criteria in the song-creation of the ašugh society of Alexandrapol, which are fully in line with Komitas's fundamental principles of Armenian national song art.
\end{abstract}

Citation: Harutyunyan H. H. (2021) Urban Music of Alexandrapole and Komitas. International Journal of Innovative Technologies in Social Science. 3(31). doi: 10.31435/rsglobal_ijitss/30092021/7687

Copyright: (C) 2021 Harutyunyan H. H. This is an open-access article distributed under the terms of the Creative Commons Attribution License (CC BY). The use, distribution or reproduction in other forums is permitted, provided the original author(s) or licensor are credited and that the original publication in this journal is cited, in accordance with accepted academic practice. No use, distribution or reproduction is permitted which does not comply with these terms.

Introduction. In his publications, lectures and letters, Komitas clearly and convincingly defines the identity standards of Armenian national music. They are justified on a vast scientific experiment and an indepth analysis of the material. Komitas has examined the complex problems of national musical thought mainly in peasant Armenian songs, as well as in various manifestations of spiritual monody. It is generally accepted that the great scientist has left his point of research view the Armenian professional secular monody; that is, the song achough.

The idea of Komitas is often quoted that ashughs use foreign melodies, which are adapted to Armenian lyrics, usually according to the rules of measurement of Arabic, Persian, or Turkish song. This idea was expressed by Komitas in one of his most interesting articles entitled "The Influence of Foreign Music on the Armenian Church and the Achough Music" [2, p. 228-229]. He also spoke about the same thing at a conference in 1905 at the Hovnanian school in Tiflis, stating that "Educated gusans are traditionally zealous for Arabic, Persian and Tajik music, although they sometimes sing songs. popular melodies but rather to amuse than to give taste because they consider it far from art, light, without style and against their school spirit. They have been singing and playing lately in Armenian, but according to the rules of Gusan poetry and the composition of Arabic, Persian and Tajik songs. In many cases, we adapt new words to already ready melodies" [1, p. 324-329].

All these affirmations attest that, nevertheless, Komitas was very well informed about the various manifestations of the Ashugh song and about its compositional etymology. In the article below he indicates that the achoughs possessed the style of the popular song and could, if desired, satisfy the popular demand [2, p. 228-229].

And the people accepted these songs as value and heritage. It is known that ashugh music and music have been characterized by national identities and several elements characterizing the culture of the Middle East. "Being one of the manifestations of epic singing, the Ashugh novel is considered as a rich repository of Armenian-Oriental musical relations, where are summarized artistic phenomena formed in neighboring cultures, involving religious ideas and popular beliefs" [3, p. 6]. 
Our program is dedicated to ashugh singing. But not only the theme of the works of a single ashugh, but the activity of the professional association of the Achoughs emphasizing the standards of identity of the Armenian national music formed and developed in this society and which were in harmony with the basic Komitassian norms of Armenian national song.

Alexandrapol is formed under the immediate influence of the traditions of West Armenian culture of Western Armenia and is truly regarded as their heir. In the 1930s displaced people mainly from Karin and Kars brought traditions, which would have reached unique manifestations in this new Armenian urban environment. The famous Armenian cities lived a flourishing life in the Middle Ages and important economic and cultural achievements were made in the nineteenth century. Handicrafts and commerce were the essential economic components of Alexandrapol residents. Thanks to Karine's immigrants from Kars and Bayazid, the city has quickly become a major trading and handicraft center of Eastern Armenia and Transcaucasia, in the city many branches of crafts have been founded, and thanks to the entrepreneurial spirit of Bayazid's skilled inhabitants, trade flourished.

As an important component of the Armenian urban culture, the ashugh tradition had a unique development in Alexandrapol which had deep roots especially in the central cities of Armenia and in the early nineteenth (nineteenth) century was established as a kind professional art or craft.

If one tries to approach the origins of this tradition, one must mention with certainty the inheritance of the traditions of Gusan Art, who has lived a few stages of development in medieval Armenian art.

It is not by chance that in the IX-XIII centuries in the list of trades in Armenia, which are not related to the production, gusan also found a place. The transition to the ashugh tradition, apparently, did not prevent to keep the craft function and the inner rule. This last corresponds completely to the peculiarities of the Armenian society of Ashughs and consequently, even to the Age acted with special codes.

Unfortunately, they did not succeed, but it was they who contributed to the preservation and development of unique crafts.

Thus, Karin's role is particularly important in shaping the trajectories of the Armenian society of the Alexandrapol Ashughs. The specialist of the study of Ashugh activities G. Levonian presented the activity of the professional society of the Alexandrapol achghs in the general aspects: "All the ashughs of this city had their union, which had its status and its administration, led by the "Bashi master" elected by all the members by a suffrage.

Near the administration there was a lending fund, whose income was formed by the monthly payments of the members. They, the Achoughs, had no stable and certain income; they were satisfied with the occasional and voluntary donations of the visitors of the cafes, or during the weddings, the feasts, where they were invited to sing and play" [4, p. 20].

For the proper functioning of the society students were also required, whose learning and status were strictly regulated. The duration of the student's learning could be 4 or 5 years. After having acquired the necessary skills, the student could address the "master Bashi" on the agreement of his master, with a request for an examination. He was admitted to take the examination in the same cafe where the master of this student played, in the presence of all the other masters achoughs.

The examined student was to play classical Ashugh works, that is, songs, but also instrumental works, mughams. In Alexandrapol was a tradition of awarding the special certificate to the title master. Like all societies, the society of the ashoughs would not be considered a complete society, if it did not have its patron saint (pure boss) or his ancestor. In most sources mention is made of the name of St. John the Baptist. To receive his blessing all the Ashoughs made the pilgrimage to Saint Karapet Monastery of Mouch, spent the night there, waiting for the vision of the sacred dreams. [5, p.7826].

Thus, the ashoughs society organized and regulated the work of the ashoughs in the city contributing to its development and natural process. Naturally, the Achoughian tradition developed in a new way in the cultural context of Alexandrapol. Let's talk briefly about the cultural territory of the Achoughs and their activity. The achough could do another activity and join another company.

In this case his activity was limited to speeches inside the city. The achough was competing in a suitable urban area or cafe. The population of the city has also participated in these competitions. The achough also had a significant presence in the city festivals. It was mainly religious rituals or other events. The achough was involved in various gatherings and family events. In Alexandrapol was also accepted the function of the family Achow. The ashough took part in the concert life of the city, with live performances. Summing up, we can say that achough controlled the expressive and 
compositional musical principles of his time. For example, it can be said with certainty that the Ashough was well acquainted with popular art and took full advantage of this rich source of musical and poetic reflection. It is not by chance that in the collection of songs by achough Chéram we see one of the famous songs, the "Sheikh Safo". It is for this main reason that several Algebra raph songs from Algarve were written by the famous Armenian musicologists G. Levonian, Sp. Melikian, Ch. Talian, K. Koushnarian, A. Kocharian, and of course, by Komitas.

Folklorist, musicologist, conductor, pedagogue and painter A. Brutyan was chiefly busy recording the songs of Ashough in Alexandrapol. As one of the best students of Komitas, he was able to correctly evaluate the multilayered heritage of Armenian national music. In the personal archives of the honored musicologist, the certificate awarded by the Archimandrite Komitas is confirmed, assuring that Brutyan mastered the new system of Armenian notation and can teach it in an educational institution.

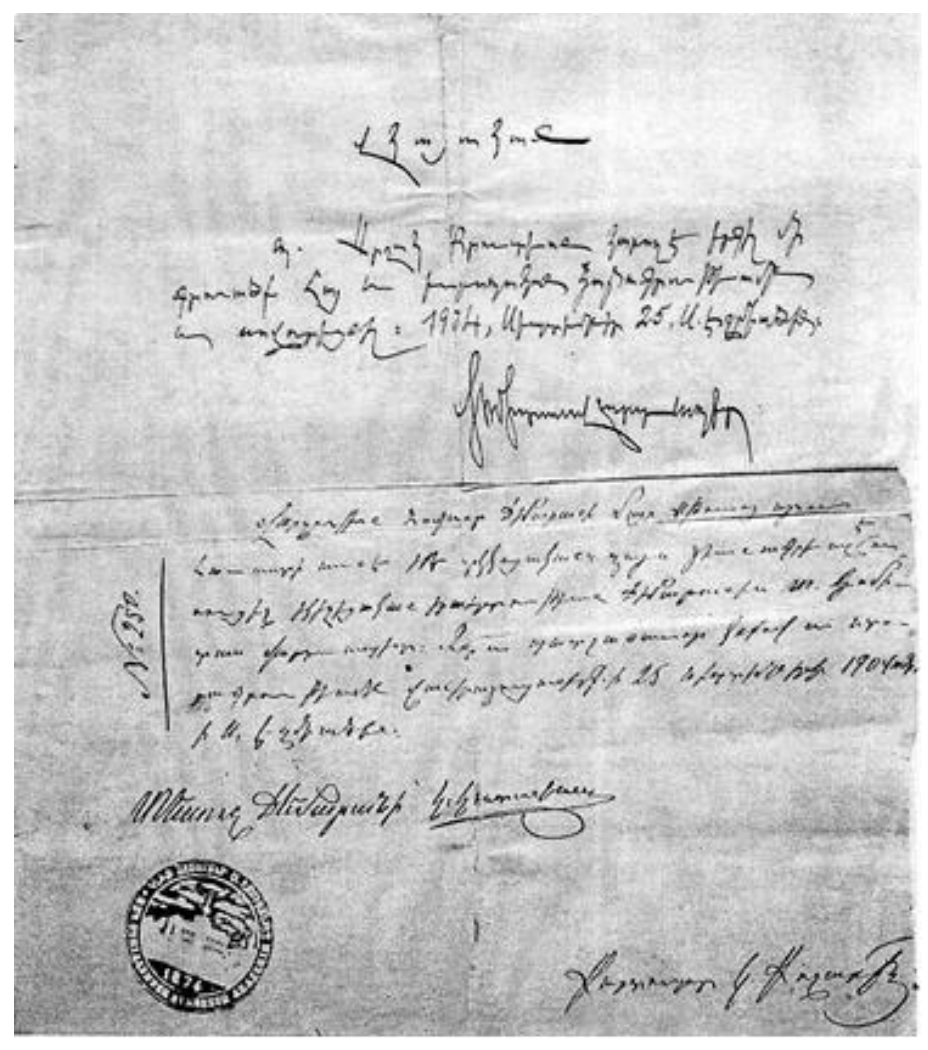

Fig. 1.

For example, the recordings of the Alexandrian songs of the Ashran songs give an idea of the stylistic and musical qualities and the local qualities of Armenian Achampian songs of the nineteenth century. The recorded samples of the (80) Armenian Ashoughs give the possibility to make a clear idea about the genre, stylistic, poetic, musical-expressive and other characteristics described in the song Ashough of Alexandrapol. These are the most important aspects of the genre of these songs, and they have probably been emphasized by Achouch. It is known that the city is particularly popular with various genres, with various subtypes. It's the patriotic songs that dominate. This, of course, was published by the High Demands and the imperative of the spirit of national liberation caractistics this period. Obviously, Brutyan has written the most popular and beloved samples of these songs. The collection also contains lyric and medieval songs, among which Brutian has also included songs that promote and disseminate Christian and scriptural arrangements in the city. The diversity of genre of songs is combined with the richness of poetic expression. As it was accepted in the art of achough, the gender content of song is largely conditioned by the metamorphic form of the given rhymes. The collection contains the following forms: dyubeit, vanaghzi, vanaghzi-mani, muhammaz, myushtezet, ghalaichi, series, dastan, the five of sema, syuverek, etc.

Speaking of the melodic and stylistic specificities of these songs, it is necessary to underline the approach adopted in the society of ashougs, according to which the poetic word bearing such or 
such rhythmic form could have been varied in several ways. In his memoirs, Alexander Achough Khayat gives valuable information on this. He clarifies his discourse in the description of the ghoshma, mentioning that the modes of this poem composed of 11 (eleven) syllables could be some, for example Kesik, Kesik Kérémi, chéki, ghalaïchi, kiryani. "By singing these melodies," he clarifies, "we used poems called ghochma" [5].

In Broutian's collection we clearly see the melodic diversity of the achoughs, which corresponds to the emotional expressiveness of the poetic image. Let's try to classify them using certain compositional standards.

Typical melodies to the popular Armenian song

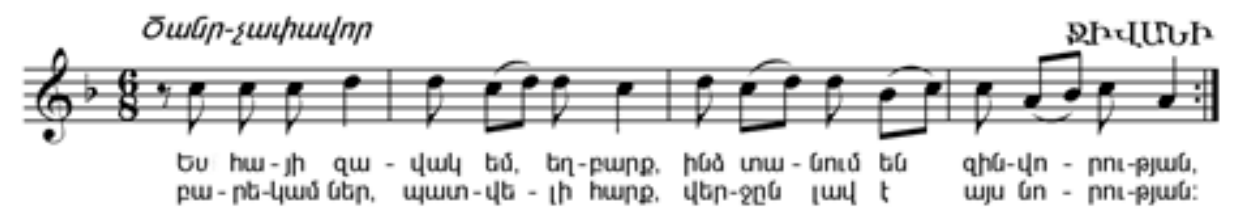

Fig. 2. One of the typical examples is the soldier's song "I am the son of an Armenian".

Typical melodies to European songs. As we know, the inseparable companion of the Armenian liberation struggle, in the nineteenth century, were patriotic songs that were born in the cultural atmosphere of the city, under the direct influence of European equivalent or harmonious songs. The Armenian ashoughs also listened to these songs and sometimes paid tribute to the creation and performance of similar songs. A typical example is the Ashough patriotic song "You've fallen asleep for so many years".

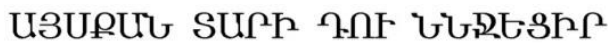

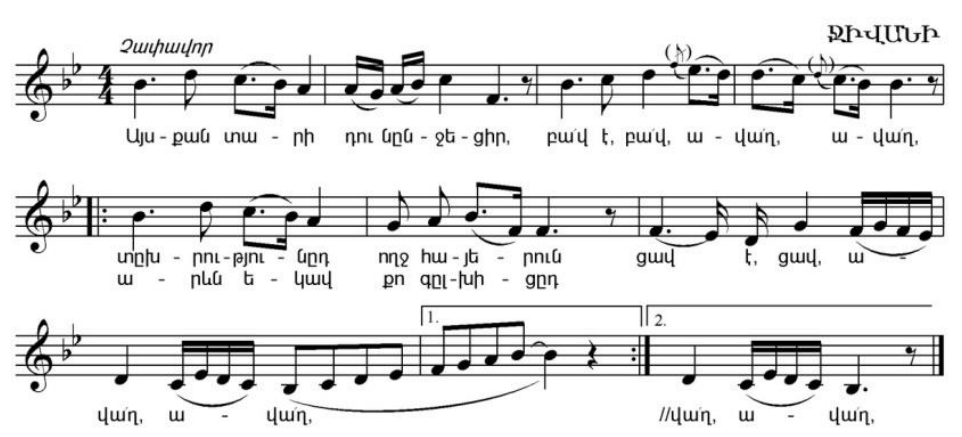

Fig. 3.

Melodies characteristic of medieval secular Armenian songs.

A large number of songs based on free melodic thought are perhaps the most typical for the creations of the ashoughs. These are high-volume compositions, the most characteristic of which are sudden nature, multilevel sound, and beautiful ornamentation. A typical example is Djivani's patriotic song "Do not leave this country".

The dramaturgical solutions of the musical composition are very deep, with a high musical mastery. Brutian's notes are also validated by the fact that there are some variations of the same ashugh song, conditioned by the professional conscience of the folklorist. Among these songs the most remarkable is the alteration of the song "I am an apricot tree" that was widespread in Alexandrapol, but later it was forgotten and we arrived thanks to this recording. The absolute majority of songs are composed in the sound system of monophonic Armenian music. In these songs many elements and principles of Armenian national music are reflected, transformed and developed in their own way. Our observations have shown that in this heritage created in the context of the Middle Eastern tradition the qualities of the Armenian folk song, the deep roots of medieval narrative and spiritual monody and the characteristics of national identity become evident. The great poluparity and good notes of today are not at random. 


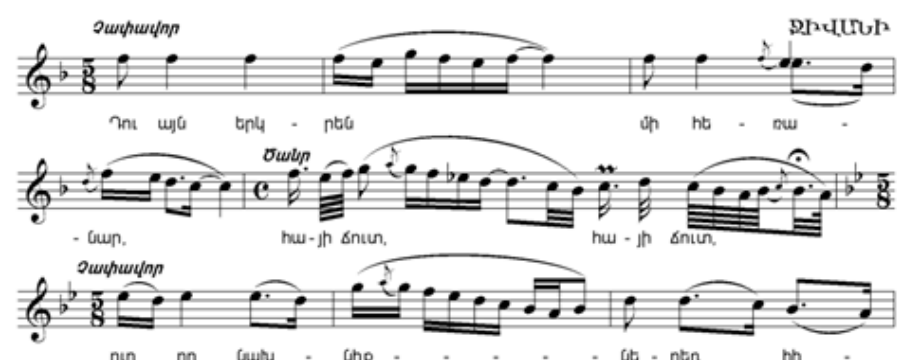

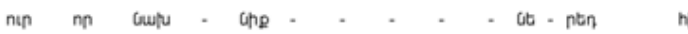
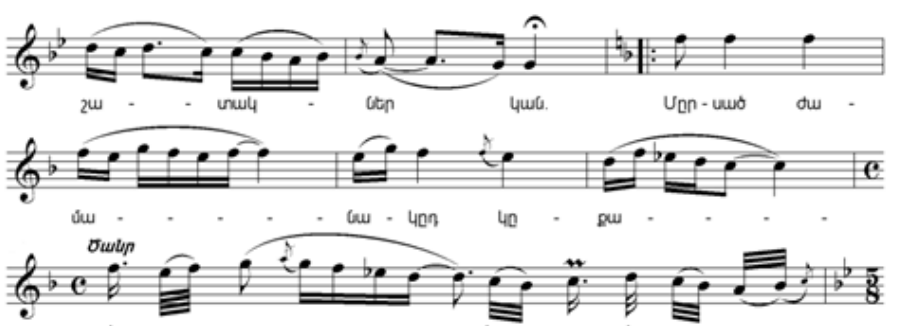

ntu $\circ$ - qnin, 40 - pus - ntu $\circ$ - qnin,

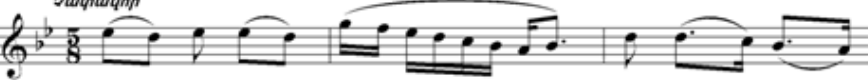

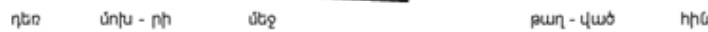
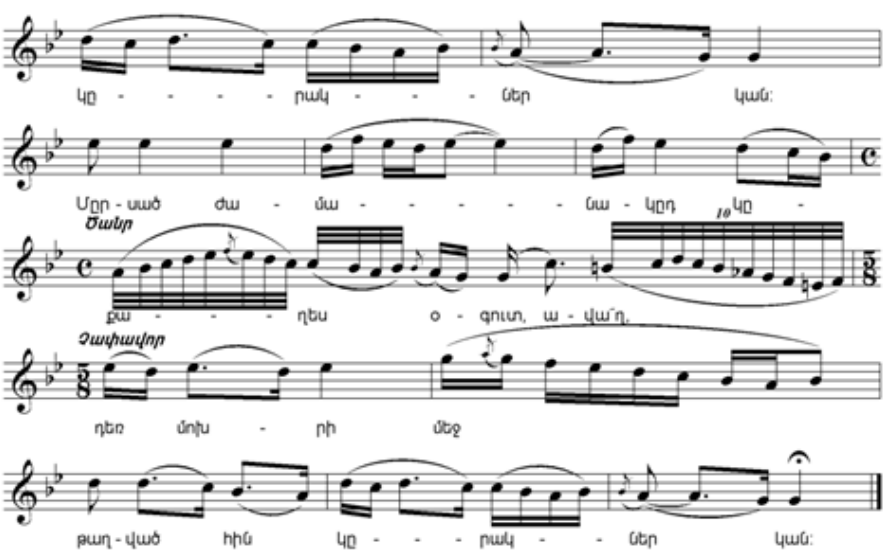

Fig. 4.

We summarize the above: in the field of the mentality of people and artistic perceptions. The arrangements of Komitas for the discovery of the national music, are in the field of artistic perception and the mentality of the people. He says: "The essence of national music is to keep the voices of such and such a way, the relation of sounds and voices (the grammatical accent and the accent of the mind, the musical accent). , the variation of the idea expressed by the word and the appropriate spontaneous melody, which is the variation of the heart, the spirit of the national music is the choice of the appropriate proportion of the song, etc. ... what is in close relationship with the song is the spirit of national music " [1, p.308-309].

Here is the memo of one of the most famous Armenian clergymen: "In my memoirs of Alexandrapol I consider myself the most Armenian and the newest, and therefore the art of Armenian achough is the most unforgettable. I must emphasize that in the Caucasus, in relation to the Armenians of Tpghis or Yerevan, the Armenians of Alexandrapol are faithful to the Armenian traditions, to the customs of the country, and the art of Armenian Achough is one of the most valuable kept him, no doubt" [6].

Conclusions. The ašugh society in Alexandrapol (now Gyumri) emerged and developed under the immediate effect of historical-cultural processes. This society carried out an important mission with the public acknowledgement it possessed. It was an embodiment of the new qualities in the Armenian national thought in all the spheres of the ašugh school: ideological, propagandistic, musicpoetic, etc. Among the songs leaning towards the Near East ašugh traditions that constituted the huge heritage of about forty ašułs, the songs based on Armenian verses display the modal, prosodic and stylistic features of Armenian monodic music. My paper presents the criteria in the song-creation of the ašugh society of Alexandrapol, which are fully in line with Komitas's fundamental principles of Armenian national song art. 


\section{REFERENCES}

1. Komitas Archimandrite. Studies and Articles, Book A, Yerevan, 2005. [Ynuhunuu Yumpuuktun.

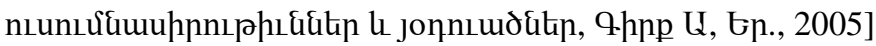

2. Komitas Archimandrite. Studies and Articles, Book B, Yerevan, 2007. [Ynúhunuu Yupnuultun.

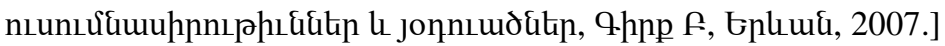

3. Yernjakyan L. Ashughakan romance in the context of Middle Eastern musical interactions, Yerevan, 2009.

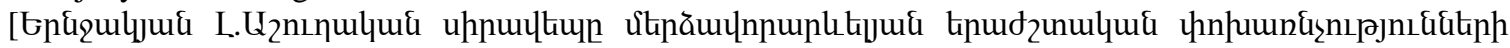
huưuuntipuinnıu, Gplıud, 2009]

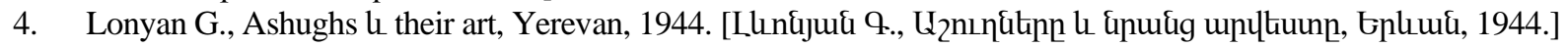

5. Khayat Zahriyan, Memoirs about ashughs, 1930, unpublished manuscript, archive of the Institute of Archeology

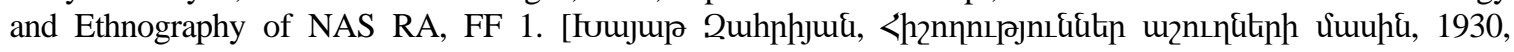

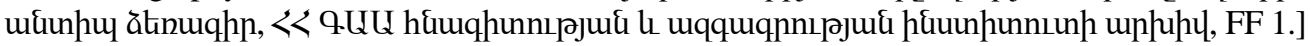

6. Bishop Babgen, in Shirak. Alexandropol, "Byzantion", No. 4/454, Constantinople, June 8-21, 1911. [คupqti

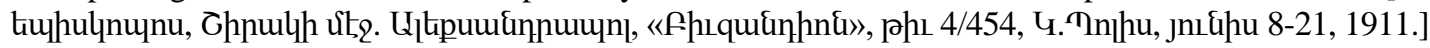

